\title{
Selenium content in Bg 350 variety of rice consumed by Sri Lankans
}

\author{
S. Mahagama ${ }^{1}$, DSM De Silva ${ }^{2 *}$, S. Wimalasena ${ }^{2}$ \\ ${ }^{1}$ Sri Lanka Standards Institution, Elvitigala Mawata, Colombo 08, Sri Lanka \\ ${ }^{2}$ Department of Chemistry, University of Kelaniya, Kelaniya, Sri Lanka
}

Received 01 ${ }^{\text {st }}$ May 2020 / Accepted 13th July 2020

\begin{abstract}
Selenium is considered as an essential micronutrient and its daily requirement is set at $55 \mu \mathrm{g} /$ day with no gender difference. Report from China has shown that an ecological correlation exists with the selenium content in the soil and increased mortality due to cancer and cardiovascular diseases with light intake of selenium. This led to the interest in assessing the nutritional status of selenium in many countries worldwide. Though, Rice is the staple food of Sri Lankans, any extensive studies on selenium content in rice grown in Sri Lanka has not been reported. Hence, the present study reports the selenium content in the $\mathrm{Bg} 350$ variety of rice and soil obtained from twelve districts (Gampaha, Colombo, Matara, Hambantota, Kegalle, Matale, Anuradhapura, Polonnaruwa, Kurunegala, Puttalam, Ampara and Monaragala), in Sri Lanka determined using Hydride Generation Atomic Absorption spectrometer (HGAAS). The results of the study showed that selenium content in rice and soil obtained from Gampaha and Colombo districts were very low and less than the detectable levels of the instrument $\left(0.5 \mu \mathrm{g} \mathrm{kg}^{-1}\right)$. Except for rice and soil from Polonnaruwa district that had a very high selenium content in rice $\left(56.9 \mu \mathrm{g} \mathrm{kg}^{-1}\right)$ and soil $\left(69.8 \mu \mathrm{g} \mathrm{kg}^{-1}\right)$, the respective values from other districts were low and ranging from $6.1 \mu \mathrm{g} \mathrm{kg}^{-1}$ (Anuradhapura)] to $13.6 \mu \mathrm{g} \mathrm{kg}^{-1}$ (Kegalle) in rice and from $9.5 \mu \mathrm{g} \mathrm{kg}^{-1}$ (Matale) to $20.3 \mu \mathrm{g} \mathrm{kg}^{-1}$ (Matara) in soil.
\end{abstract}

Key words: Selenium, paddy, rice, Bg 350, soil, Sri Lanka

\footnotetext{
*Corresponding author Email: sujeewa@kln.ac.lk;

(1) http://orcid.org/0000-0002-8631-3838

DOI: http:://doi.org/10.4038/josuk.v13i0.8023
}

This is an open access article distributed under the terms of the Creative Commons Attribution 4.0 International License, which permits unrestricted use, distribution and reproduction in any medium provided the original work are properly credited. 


\section{S. Mahagama et al.}

\section{INTRODUCTION}

Selenium is a trace metal found in the earth crust. It enters plant food through the soil and the contents depends on type of soil, climate conditions, geographical area and ability of plant to accumulate selenium. In human body there are several selenoprotiens (Comb, 2001), such as glutathiase peroxidase that act as an antioxidant and prevent lipid peroxidation and cellular damage, thereby preventing several degenerative diseases, cancer, DNA damage and aging (Briggs, 1999). Selenium is also essential for the synthesis of thyroid hormones and its deficiency results in iodine diffidence in human (Neve, 1996). Hence, the selenium has been recommended as a micronutrient and the World Health Organization (1994) has set the average intake of selenium for human as $40 \mu \mathrm{g} /$ day and its tolerable upper intake level as $400 \mu \mathrm{g} /$ day. Selenium enters the human body through the consumption of food and water. The foods, such as meat, seafood, milk, eggs, vegetables, green leaves and cereals were identified as good sources of selenium (Comb, 2001; De Silva et al., 2019).

Recent interest on selenium content in food resulted due to reports on Keshan disease and Kishin-back disease that prevailed in china related to deficiency in selenium content in dietary intake (Yang et al., 1987). Selenium content in common food consumed by people of other countries have been reported but those by Sri Lankans is rare, except for a few studies reported from cereals and legumes (Buwaneka et al., 2014), complete dietary meals (Kiridena et al., 2017), green leaves (De Silva et al., 2019) and rice from three selected goiter incidence villages in Sri Lanka (Fordyce et al., 2000). Further, in the study of Fordyce, et al., the selenium levels in water, soil, rice and human hair were determined and identified that a significant amount of Sri Lankan female population are under risk of selenium deficiency. Therein, the selenium levels were found to be 0.113 $5.238 \mu \mathrm{g} \mathrm{g}^{-1}$ in soil, $0.06-0.24 \mu \mathrm{g} \mathrm{L}^{-1}$ in water, $0.1-0.776 \mu \mathrm{g} \mathrm{g}^{-1}$ in rice and $0.104-2.652$ 
$\mu \mathrm{g} \mathrm{g}^{-1}$ in human hair. They also concluded an associate of Iodine Deficiency, particularly the onset of goiter in Sri Lanka with the selenium deficiency. In the recent past it has been identified that selenium deficiency may be a contributory factor in the occurrence of chronic kidney disease of unknown etiology (CKDu) (Jayathilake et al., 2013) which is prevailing among the dry zone farming communities in Sri Lanka. Also according to a report of WHO, low serum selenium levels have been reported in people with $\mathrm{CKDu}$ in Sri Lanka, inferring possible correlation between selenium deficiency and susceptibility to $\mathrm{CKDu}$ (WHO, 2013).

A few studies were reported on selenium in rice from other countries (Spaliholz et al., 2008; Chen et al., 2002; Yoshida et al., 1987). Considering the importance in selenium in food consumed by Sri Lankan communities, and as no extended study has been reported on selenium in rice, the staple food of Sri Lankans, this study aims at deducing the selenium content in rice in order to find whether rice could supply most of the selenium required by Sri Lankans. In order to achieve this objective selenium content in paddy, rice and soil from selected fields in 12 districts were studied.

\section{MATERIALS AND METHODS}

All chemicals used were AR grade. $\mathrm{Na}_{2} \mathrm{Se}_{2} \mathrm{O}_{3} .5 \mathrm{H}_{2} \mathrm{O}$ was used as the selenium standard. Deionized water was used in preparing samples and reagents. Analysis was carried out in the laboratories of the Department of Chemistry, University of Kelaniya, Sri Lanka. Selection of sampling sites were based on the field survey carried out by the responses given by the questionnaire distributed to 150 farmers. Sampling was carried out as SLS specification requirements and methods of sampling and test for paddy (SLS 632: 1994). 


\section{S. Mahagama et al.}

Samples of the $\mathrm{Bg} 350$ variety of rice was obtained from selected fields (i.e. 5 fields per district) in 12 districts (Gampaha, Colombo, Matara, Hambantota, Kegalle, Matale, Anuradhapura, Polonnaruwa, Kurunegala, Puttalam, Ampara and Monaragala)

(Table 1) where seeds and fertilizers were supplied from the same supplier.

Table 1. Sampling Locations of Soil and Paddy

\begin{tabular}{|l|l|l|c|c|}
\hline Province & District & Farming area & $\begin{array}{l}\text { Number of } \\
\text { fields }\end{array}$ & $\begin{array}{l}\text { Number of primary } \\
\text { samples per field }\end{array}$ \\
\hline Western & Gampaha & Daraluwa & 05 & 10 \\
\cline { 2 - 5 } & Colombo & Hanwella & 05 & 10 \\
\hline Southern & Matara & Godagama & 05 & 10 \\
\cline { 2 - 6 } & Hambantota & Tangalle & 05 & 10 \\
\hline Sabaragamuwa & Kagalle & Galigamuwa & 05 & 10 \\
\hline Nontral & Matale & Dambulla & 05 & 10 \\
\cline { 2 - 6 } & Anuradhapura & Talawa & 05 & 10 \\
\cline { 2 - 6 } & Polonnaruwa & Giritale & 05 & 10 \\
\hline North Western & Kurunegala & Wariyapola & 05 & 10 \\
\cline { 2 - 6 } & Puttalam & Nikaweratiya & 05 & 10 \\
\hline Evastern & Ampara & Ampara & 05 & 10 \\
\hline
\end{tabular}

\section{Paddy and rice Samples}

Ten bags from the paddy were selected randomly from each field. Fifty primary samples of approximate $100 \mathrm{~g}$ were obtained from each bag by penetrating a sample scoop randomly through the top, middle and bottom position of each bag. The primary samples obtained were combined ( $5 \mathrm{~kg}$ ) and laid on a flat surface. The foreign matters such as straws, weeds, stones and soil particles were removed by visual inspection. The samples 
were then winnowed to remove the chars. Each sample was thoroughly mixed manually to obtain homogeneous primary sample. A composite sample $(2 \mathrm{~kg})$ was obtained as above from the primary sample.

Working samples of rice (100 g) were prepared by removing the husk from random selection obtained from the composite sample. The rice samples were then oven dried at $95 \pm 5^{\circ} \mathrm{C}$ and powdered using and electrical grinder.

\section{Soil samples}

The sown area of paddy in a field from where rice was obtained was considered as the lot to obtain soil samples with respect to the drawn paddy samples. The maximum sampling depth was maintained at $10 \mathrm{~cm}$. The samples were drawn from five positions (four sides and middle) from each field in five consecutive fields. Twenty five primary samples (200 g each) were obtained from a field. From the primary soil samples, a composite sample $(1 \mathrm{~kg})$ was obtained by random selection. The samples were oven dried at $95 \pm 5^{\circ} \mathrm{C}$ till a constant weight was obtained.

\section{Selenium analysis}

Accurately weighted working samples $(2.000 \mathrm{~g})$ of paddy, rice and soil were digested with conc. $\mathrm{HNO}_{3}$ acid $(30.00 \mathrm{~mL})$ at $90 \pm 5^{\circ} \mathrm{C}$ for 2 hours till effervescence of brown fumes ceased. The acid extract was then heated at $60{ }^{\circ} \mathrm{C}$ with $\mathrm{H}_{2} \mathrm{O}_{2}(30 \%, 6.00$ $\mathrm{mL}$ ) repeatedly till effervescence ceased. The extract was concentrated to $5 \mathrm{~mL}$, cooled to room temperature and filtered, diluted with conc. $\mathrm{HCl}(15 \mathrm{~mL})$ and make up to 25.00 $\mathrm{mL}$ with deionized water in a volumetric flask. The digested sample was heated with $\mathrm{NaBH}_{4}(0.6 \%)$ in $\mathrm{NaOH}(0.6 \%)$ and $\mathrm{HCl}(5 \%)$. The selenium content in the samples were determined using GBC HG 3000 Hydride Generation Atomic Absorption Spectrometer after optimizing the conditions. $\mathrm{Na}_{2} \mathrm{Se}_{2} \mathrm{O}_{3} .5 \mathrm{H}_{2} \mathrm{O}$ was used as the selenium standard. The 
results were subjected to one way ANOVA method and TUCKY's pair wise comparison at $95 \%$ confidence level.

\section{RESULTS and Discussions}

The paddy and soil samples were obtained from five selected fields from earlier mentioned 12 districts in Sir Lanka. The fields were selected on the basis of a questionnaire distributed to farmers. Based on this survey, $\mathrm{Bg} 350$ variety of paddy were collected from fields for which the seeds and fertilizers were supplied from the same supplier. The fertilizers that were applied for the selected fields were muriate of potash, tipple superphosphate and urea.

The results of the present study (Table 2, Figure 1) showed that selenium content in paddy and soil obtained from Gampaha and Colombo districts were very low and below the limit of detection $\left(0.5 \mu \mathrm{g} \mathrm{kg}^{-1}\right)$. The paddy and soil obtained from Polonnaruwa district had a very high content of selenium. The respective values were $61.2 \mu \mathrm{g} \mathrm{kg}^{-1}$ and $69.8 \mu \mathrm{g}$ $\mathrm{kg}^{-1}$ while those from other districts were low. The values in other districts were in the range of $6.3 \mu \mathrm{g} \mathrm{kg}^{-1}$ (Anuradhapura) to $13.8 \mu \mathrm{g} \mathrm{kg}^{-1}$ (Kegalle) for paddy and $9.5 \mu \mathrm{g} \mathrm{kg}^{-1}$ (Matale) to $20.3 \mu \mathrm{g} \mathrm{kg}^{-1}$ (Matara) for soil.

Table 2: Selenium content in paddy, rice and soil and \% incorporation of selenium in rice from paddy

\begin{tabular}{|l|l|c|c|c|c|}
\hline & \multicolumn{1}{|c|}{ District } & $\begin{array}{c}\text { Se in paddy } \\
\left(\mu \mathrm{g} \mathrm{kg}^{-1}\right)^{*}\end{array}$ & $\begin{array}{c}\text { Se in rice } \\
\left(\mu \mathrm{g} \mathrm{kg}^{-1}\right)^{*}\end{array}$ & $\begin{array}{c}\text { Se in soil } \\
\left(\mu \mathrm{g} \mathrm{kg}^{-1}\right)^{*}\end{array}$ & $\begin{array}{c}\text { \% Incorporation of Se } \\
\text { in rice from paddy }\end{array}$ \\
\hline 01 & Gampaha & $<\mathrm{LOD}$ & $<\mathrm{LOD}$ & $<\mathrm{LOD}$ & $<$ LOD \\
\hline 02 & Colombo & $<\mathrm{LOD}$ & $<\mathrm{LOD}$ & $<\mathrm{LOD}$ & $<$ LOD \\
\hline 03 & Matara & $13.1^{\mathrm{a}} \pm 0.2$ & $12.6^{\mathrm{a}} \pm 1.4$ & $20.3^{\mathrm{a}} \pm 0.9$ & 95.6 \\
\hline
\end{tabular}




\begin{tabular}{|l|l|c|c|c|c|}
\hline 04 & Hambantota & $13.0^{\mathrm{a}} \pm 0.1$ & $12.7^{\mathrm{a}} \pm 0.9$ & $14.1^{\mathrm{b}} \pm 0.4$ & 97.9 \\
\hline 05 & Kegalle & $13.8^{\mathrm{b}} \pm 0.7$ & $13.6^{\mathrm{a}} \pm 1.1$ & $15.4^{\mathrm{b}} \pm 0.7$ & 98.0 \\
\hline 06 & Matale & $7.8^{\mathrm{c}} \pm 0.2$ & $7.5^{\mathrm{b}} \pm 1.1$ & $9.5^{\mathrm{c}} \pm 0.4$ & 96.1 \\
\hline 07 & Anuradhapura & $6.3^{\mathrm{c}} \pm 0.3$ & $6.1^{\mathrm{b}} \pm 1.5$ & $10.1^{\mathrm{c}} \pm 0.3$ & 97.8 \\
\hline 08 & Pollanaruwa & $61.2^{\mathrm{d}} \pm 3.4$ & $56.9^{\mathrm{c}} \pm 6.9$ & $69.8^{\mathrm{d}} \pm 0.4$ & 93.1 \\
\hline 09 & Kurunegala & $10.3^{\mathrm{e}} \pm 0.8$ & $9.6^{\mathrm{d}} \pm 1.2$ & $11.2^{\mathrm{c}} \pm 0.7$ & 94.0 \\
\hline 10 & Puttalam & $11.0^{\mathrm{e}} \pm 1.1$ & $10.8^{\mathrm{d}} \pm 0.9$ & $11.8^{\mathrm{c}} \pm 0.8$ & 97.9 \\
\hline 11 & Ampara & $8.3^{\mathrm{c}, \mathrm{f}} \pm 0.8$ & $8.02^{\mathrm{b}, \mathrm{e}} \pm 1.0$ & $18.7^{\mathrm{e}} \pm 0.4$ & 96.3 \\
\hline 12 & Monaragala & $8.2^{\mathrm{c}, \mathrm{f}} \pm 1.1$ & $7.8^{\mathrm{b}, \mathrm{e}} \pm 0.9$ & $18.4^{\mathrm{e}} \pm 0.6$ & 95.2 \\
\hline
\end{tabular}

LOD: Limit of detection $\left(0.5 \mu \mathrm{g} \mathrm{kg}^{-1}\right)$.

*Mean \pm standard deviation of analysis done in triplicate

Means with same letter in the column do not differ significantly when statistically analyzed by one way ANOVA \& TUCKY's pair wise comparison at 95\% confidence level.

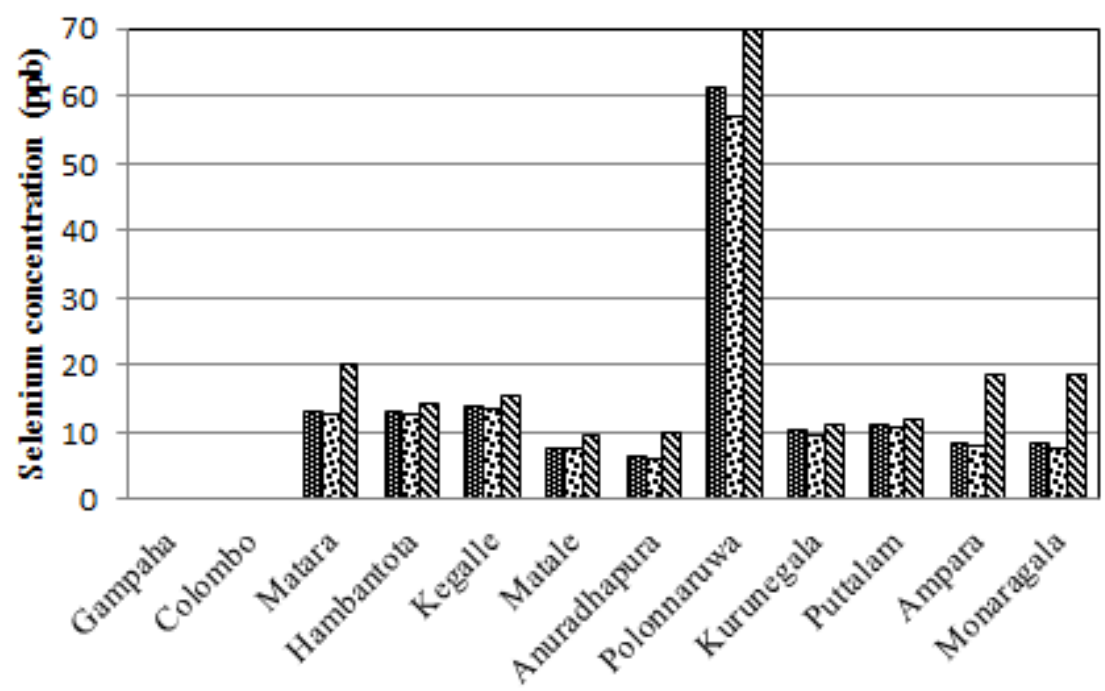

Selenium in paddy $(\mu \mathrm{g} / \mathrm{kg})^{*}$ $\square$ Selenium in rice $(\mu \mathrm{g} / \mathrm{kg})^{*}$

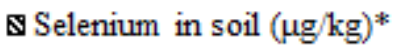

Districts

Figure 1: Comparison of selenium content in paddy, rice and soil from different districts 


\section{S. Mahagama et al.}

Selenium content in rice reported by Fordyce et al. (2000) were higher (100-776 $\mu \mathrm{g} \mathrm{kg}^{-1}$ ) than those obtained in the present study. The results of Fordyce et al. study cannot be compared with those of the present study as rice was obtained from 15 villages selected on the basis of low, medium and high incidences of goiter reported from Sri Lanka and did not obtained from grain stores in the area and also the variety and the source were not known.

Studies on selenium content in rice from other countries is rare. Study carried out in Bangladesh showed that the selenium content in rice was $105-212 \mu \mathrm{g} \mathrm{kg}^{-1}$ while that from Japan; $43 \pm 27 \mu \mathrm{g} \mathrm{kg}^{-1}$ and China; $25 \pm 11 \mu \mathrm{g} \mathrm{kg}^{-1}$ (Zakaria, 2008; Yoshida, 1987; Chen 2002) . The selenium in rice from above mentioned countries were higher than those obtained from most of the villages except for the content in paddy from Polonnaruwa district $(61.2 \mu \mathrm{g} / \mathrm{kg})$. The values reported from other countries cannot be compared with those from present study as the geographical variations contributing to the content in soil and it is not specified whether selenium containing fertilizer has not been used.

There was statistical differences in the content of selenium in rice, paddy and soil from same district. The selenium content in rice showed a positive co-relation with that of soil $\left(\mathrm{R}^{2}=0.9538\right)$. According to the data obtained from the Registrar of Pesticide, Sri Lanka and from fertilizer companies, the farmers under the government subsidiary fertilizer used for paddy cultivation do not contain selenium and all selenium containing fertilizers are distributed for those engaged in tea plantation. Hence, the variation in the selenium content in soil obtained from different districts is not due to fertilizer but due to selenium in earth crust and its soil adsorption and retention in water.

The results of the present study showed that very high content of selenium is incorporated into rice from paddy (93.1-98\%). Hence, selenium is found mainly in the 
seed and not in the husk. Further, this study revealed that selenium obtained from rice in Sri Lankan daily meal was very low. But the study carried out by Kiridena et al (2017) showed that a daily meal of Sri Lankans that comprises of rice, cereals, vegetables, meat and fish is rich in selenium (40-70 $\left.\mu \mathrm{g} \mathrm{kg}^{-1}\right)$ and meets the daily requirement postulated by WHO. An average Sri Lankan meal contains about $200 \mathrm{~g}$ of rice, hence, the people in Polonnaruwa do not reach the toxic level even by taking meals with rice in all three meals of the day. Hence, fertilizers used in paddy cultivation in Sri Lanka need not be supplemented with selenium to enhance the selenium content in rice.

\section{CONCLUSIONS}

The study revealed that the selenium content in rice and soil obtained from Gampaha and Colombo districts were very low. Further, rice and soil from Polonnaruwa district had a very high selenium content in rice $\left(59.6 \mu \mathrm{g} \mathrm{kg}^{-1}\right)$ and soil $\left(69.8 \mu \mathrm{g} \mathrm{kg}^{-1}\right)$ and the respective values from other districts were low and ranging from $6.1 \mu \mathrm{g} \mathrm{kg}^{-1}$ (Anuradhapura)] to $13.6 \mu \mathrm{g} \mathrm{kg}^{-1}$ (Kegalle) in rice and from $9.5 \mu \mathrm{g} \mathrm{kg}^{-1}$ (Matale) to 20.3 $\mu \mathrm{g} \mathrm{kg}^{-1}$ (Matara) in soil.

Thought the contribution from rice to the daily requirement of selenium is very low, when consumed with other selenium rich food such as cereals and legumes, the meals consumed by Sri Lankans, provide the daily requirement. Hence, there is no necessity of supplementing fertilizers used in paddy cultivation in Sri Lanka with selenium to enhance the selenium content in rice. 


\section{S. Mahagama et al.}

\section{REFERENCES}

Briggs S. (1999), Selenium antioxidant and cancer: A review of literature alternative medicine review, 3:239-253.

Buwaneka P.A., De Silva D.S.M., Wimalasena S. and Kannangara A.T. (2014), Determination of Selenium content in cereals and legume seeds grown in Sri Lanka, International Research Symposium on Post-Harvest Technology Institute of Post-Harvest Technology, Sri Lank, 27-32.

De Silva, D. S. M. and Dayarathna (2019), A. G. S., Determination of selenium content in selected edible green leaves, Ceylon Journal of Science 48(1), 61-65.

Kiridena K.M.S.D, De Silva D.S.M, Wimalasena S. (2017), Selenium content in meals consumed for lunch by Sri Lankans and the effect of cooking on selenium conten, Ceylon Journal of Science 46(4): 21-25.

Chen, L., Yang, F., Xu, J., Hu, Y., Hu, Q., Zhang, Y. and Pan, G. (2002), Determination of Selenium Concentration of Rice in China and Effect of Fertilization of Selenite and Selenate on Selenium Content of Rice, Journal of Agricultural and Food Chemistry 50(18), pp.5128-5130.

Comb G.F. (2001), Selenium in global food systems, British Journal of Nutrition 85, 517 547.

Fordyce F.M., Johnson C.C, Navaratna U.R.B., Appleton J. D., Dissanayake C.B (2000), Selenium and iodine in soil, rice and drinking water in relation to endemic goitre in Sri Lanka, The Science of Total Environment 263: 127-141.

Jayatilake N., Mendis S., Maheepala P., Mehta F.R. (2013), Chronic kidney disease of uncertain aetiology: prevalence and causative factors in a developing country, BMC Nephrology, 14:180.10.1186/1471-2369-14-180. 
Neve J. (1996), Selenium as a risk factor for cardiovascular disease, Journal of cardiovascular Risk 3: 42-47.

Spallholz J., Mallory B. L., Mahmububur R. M., Katz D., David R. J., Zakaria A., Khan A., Alauddin, M., Bhattacharjee M., Sultana S., Khana S. and Choucair Z. (2008), Selenium content of rice, mixed plant foods and fish from Bangladesh, Toxicological \& Environmental Chemistry 90(2), 211-220.

World Health Organization (1996), Selenium in trace element in human nutrition and health, 105-122, Geneva.

World Health Organization (2013), Investigation and evaluation of chronic kidney disease of uncertain aetiology in Sri Lanka, Final Report.

Yang G Q, Qian P.C., Zhu L.Z., Huaug J.H., Liu S.J and Lu M.D (1987), Human selenium requirements in China, Selenium Biology and Medicine. Vol. A, 589594.

Yoshida M. and Yasumoto K. (1987), Selenium contents of rice grown at various sites in Japan, Journal of Food Composition and Analysis 1(1), 71-75. 